\title{
SALT KARST AND COUAPSE STRUCTURES IN THE ANADARKO BASIN OF OKLAHOMA AND TEXAS
}

\author{
Kenneth S. Johnson \\ Oklahoma Geological Survey, 1321 Greenbriar Dr., Norman, OK 73072, USA, ksjohnson@ou.edu
}

\begin{abstract}
Permian bedded salt is widespread in the Anadarko Basin of western Oklahoma and the Texas Panhandle, where partial or total dissolution of the shallowest salt in some areas has resulted in subsidence and/or collapse of overlying strata. Groundwater has locally dissolved these salts at depths of 10-250 m. The distribution (presence or absence) of salt-bearing units, typically $80-150 \mathrm{~m}$ thick, is confirmed by interpretation of geophysical logs of many petroleum tests and a few scattered cores. Salt dissolution by ground water is referred to as "salt karst."

Chaotic structures, collapse features, breccia pipes, and other evidence of disturbed bedding are present in Permian, Cretaceous, and Tertiary strata that overly areas of salt karst. The dip of Permian and post-Permian strata in the region normally is less than one degree, mainly towards the axis of the Anadarko Basin. Where strata locally dip in various directions at angles of 5-25 degrees or more, and underlying salt units show clear evidence of dissolution, these chaotic dips must result (mostly, if not totally) from subsidence and collapse into underlying salt-dissolution cavities.
\end{abstract}

Gypsum karst and resultant collapse of overlying strata have been proposed in many parts of the Anadarko Basin. However, the gypsum beds typically are only 1-6 $\mathrm{m}$ thick and more than $100 \mathrm{~m}$ deep, and cannot contribute to disruption of outcropping strata-except where they are within $10-20 \mathrm{~m}$ of the surface.

Typical areas of disturbed bedding comprise several hectares, or more, with outcrops of moderately dipping strata-as though large blocks of rock have foundered and subsided into large underground cavities. Other examples of disturbed bedding are small-diameter breccia pipes, or chimneys, that extend vertically up from salt-karst cavities, through several hundred meters of overlying strata. The best evidence of these chimneys are collapsed blocks of Cretaceous strata, chaotically dropped some $50 \mathrm{~m}$, or more, that are now juxtaposed against various Permian formations on the north flank of the Anadarko Basin. Any study of surface or shal- low-subsurface geology in the Anadarko Basin must consider the influence of subsurface salt karst on the structure and distribution of overlying rocks.

\section{Introduction}

The current study summarizes years of investigations of salt karst and resultant collapse features in and around the Anadarko Basin of western Oklahoma and the Texas Panhandle. These investigations have involved integrated studies of: 1) the subsurface distribution and thickness of Permian salt beds; and 2) field studies to identify areas where outcropping strata are disrupted and disturbed.

Subsurface studies have been carried out mainly by recognition of salt and associated strata on electric logs (also known as "geophysical logs") of oil and gas tests, as well as examination of several cores of salt units in the basin. Identification of evaporites and associated rock types on electric logs is well established (Alger and Crain, 1966), and I have carried out many studies using various types of well logs to identify, correlate, and map salt and gypsum beds in the subsurface-some of the studies are in public documents (Johnson, 1967, 1981, 1989b, 1993), and many others are in consulting reports. Also of special value for this study are the cross sections of Permian evaporites in the Anadarko Basin by Jordan and Vosburg (1963).

In the Anadarko Basin, Permian strata typically are gently dipping or horizontal, with dips normally being less than $10 \mathrm{~m} / \mathrm{km}$ (less than one degree) towards the axis of the basin. Therefore, where dips are several degrees, or more, and particularly where strata dip chaotically in different directions within short distances, it is most likely a result of dissolution of underlying Permian evaporites (salt and gypsum) and collapse of younger strata into the solution cavities. In most areas the gypsum beds are 1-6 m thick, so their dissolution would not normally disrupt overlying rocks, except where the gypsum bed(s) are less than about $20 \mathrm{~m}$ below the land surface. On the other hand, salt units typically are 50-150 m thick, and salt-dissolution cavities can be 
quite large and can result in collapse of several hundred meters of overlying strata.

Four examples of salt dissolution and collapse are described in this report to show the geographic range of salt karst and resultant collapse in the Anadarko Basin. These examples are in Beckham, Washita, and Beaver Counties, Oklahoma, and in Hansford County, Texas (Figure 1).

\section{Geologic Setting of Anadarko Basin}

The Anadarko Basin is the deepest sedimentary and structural basin in the interior of the United States (Johnson and others, 1988; Johnson, 1989a). Paleozoic sedimentary rocks are as much as $12,000 \mathrm{~m}$ thick along the axis of the basin, and Permian strata (which contain the salt units) are as much as 2,100 m thick. Outcropping strata in the basin are predominantly Permian, Tertiary, and Quaternary in age, with some scattered small outliers of mostly collapsed Cretaceous rocks.

The basin is bounded on the south by the Wichita and Amarillo uplifts (Figure 1), and on the east and west by the Nemaha uplift and the Cimarron arch, respectively,

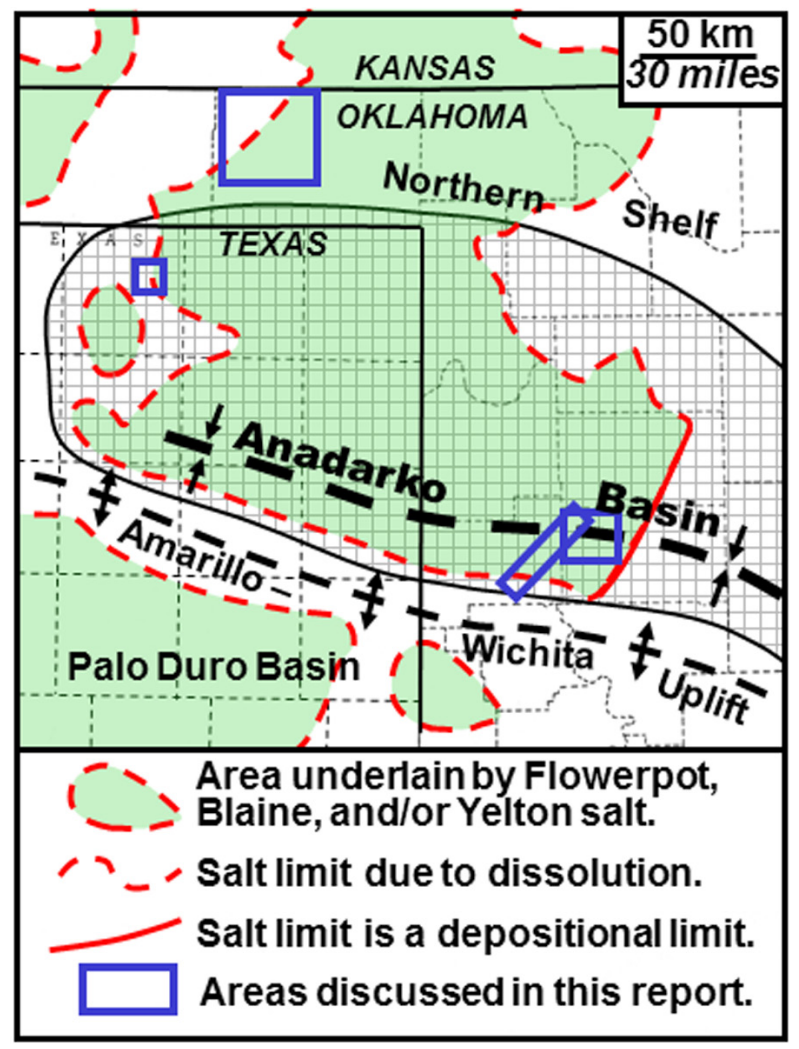

Figure 1. Map of Anadarko Basin in western Oklahoma and Texas Panhandle, and dissolution limit of areas underlain by the Flowerpot, Blaine, and/or Yelton salts. both of which are outside the region under investigation. The northern shelf of the basin extends across northern Oklahoma and much of western Kansas. The basin is asymmetrical, with the axis located close to its south flank.

Following a Late Cambrian through Mississippian epeirogenic episode, the basin underwent a period of orogenic activity when the Wichita-Amarillo uplift was thrust up and the adjacent Anadarko Basin subsided to receive nearly 5,500 $\mathrm{m}$ of Pennsylvanian-age clastics and carbonates. This was followed by a late epeirogenic episode that began in Permian time and has persisted till today.

Most Permian sediments in the Anadarko Basin are redbeds, evaporites, and marine carbonates. They were deposited mainly in fairly shallow water, although some of the redbeds are of deltaic, aeolian, or alluvial origin. Evaporites include anhydrite (gypsum at and near the outcrop), salt (halite), and variable mixtures of salt and shale; potash salts and other evaporites have not been found in the basin.

The principal evaporite units involved in this study are, in ascending order, the Flowerpot salt, the Blaine Formation (gypsum/anhydrite and salt), and the Yelton salt (Figure 2). These units have been grouped into the Beckham evaporites by Jordan and Vosburg (1963), and the region underlain by salt in these units is shown in Figure 1. The total thickness of the salt-bearing Beckham evaporites is as much as 150-220 m along the axis of the Anadarko Basin in Beckham and Washita Counties, Oklahoma, where all three of the evaporite units contain significant salt deposits (Johnson, 1963, 1976; Jordan and Vosburg, 1963).

\section{Salt Karst}

Salt (halite, $\mathrm{NaCl}$ ) is extremely soluble in fresh water. Halite solubility in water is $35 \%$ by weight at $25^{\circ} \mathrm{C}$, and it increases at higher temperatures. The four basic requirements for dissolution of salt and development of salt karst, are: 1) a deposit of salt against which, or through which, water can flow; 2) a supply of water unsaturated with $\mathrm{NaCl}$; 3) an outlet whereby the resulting brine can escape; and 4) energy (such as a hydrostatic head or density gradient) to cause the flow of water through the system (Johnson, 1981). When all four of these requirements are met, dissolution of salt can be quite rapid, in terms of geologic time. 


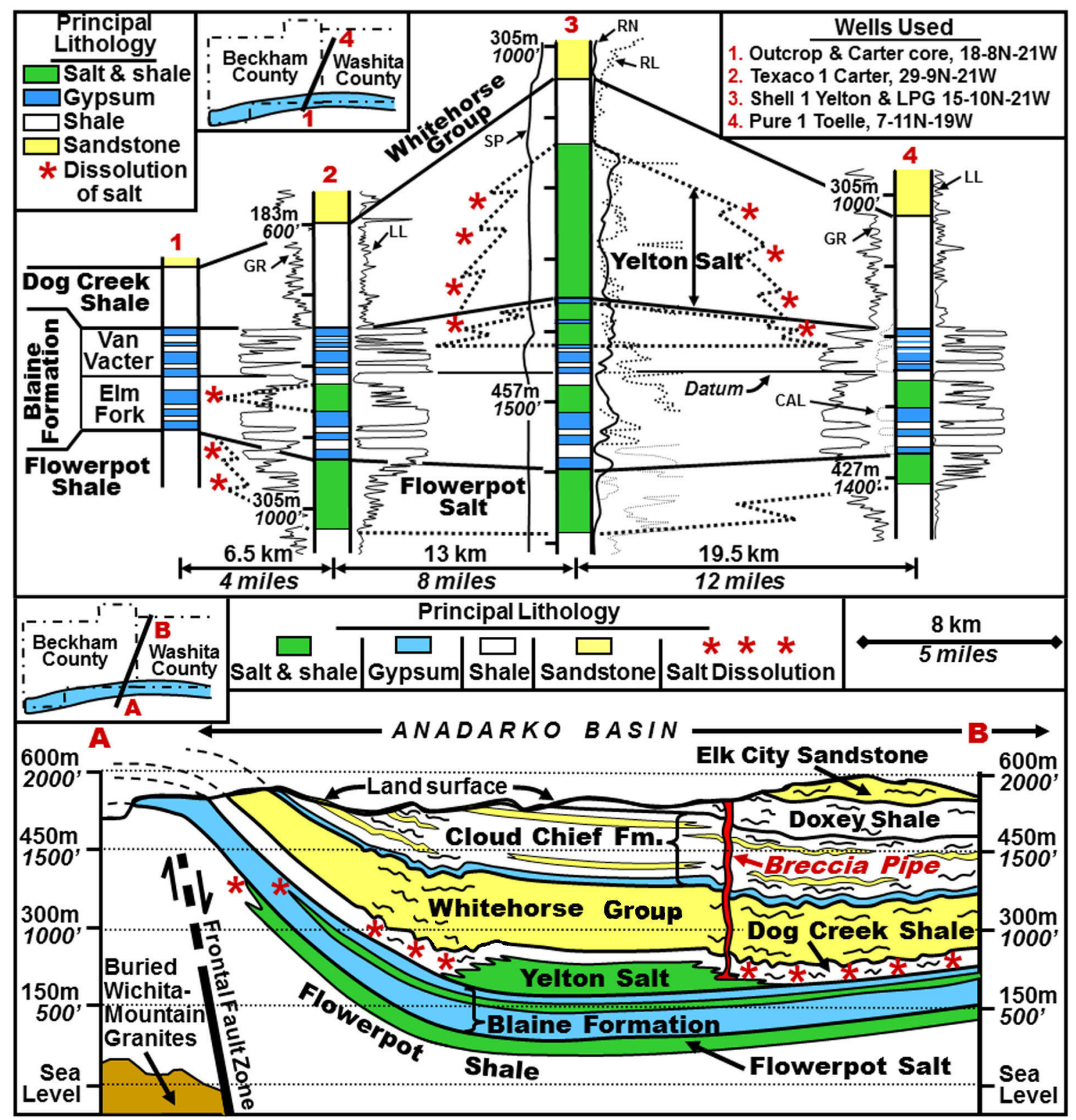

Figure 2. Cross sections showing dissolution of Permian salt units in eastern Beckham and western Washita Counties, Oklahoma. Upper stratigraphic cross section (Johnson, 1967, Plate II) and lower structural cross section (Johnson, 1963) are along the same alignment.

Permian salt deposits in the Anadarko Basin have been dissolved locally by ground water, and this is still going on, as attested by several natural springs that emit brines formed by dissolution of the salt on the north and south flank of the Anadarko Basin in Oklahoma (Johnson, 1981). Most salt karst in the Anadarko Basin occurs in the Yelton, Blaine, and Flowerpot salts (Beckham evaporites), because these are the shallowest salts; the depth to the top of these salts typically ranges from 10 to $350 \mathrm{~m}$ below the present land surface (Figure 2). The present-day depth to salt-dissolution zones ranges from 10-250 m.

\section{Collapse Structures}

The normal dip of strata in the Anadarko Basin is less than one degree (less than $10 \mathrm{~m} / \mathrm{km}$ ) towards the axis of 
the basin. However, dissolution of salt has resulted in a number of collapse structures, and in places underlain by salt karst the overlying strata have subsided, settled, or collapsed into the underground cavities (Figure 2). This has resulted in disturbed bedding in outcropping rocks. Disturbed bedding and collapse structures caused by salt karst in the Oklahoma portion of the Anadarko Basin can be seen not only in outcrops of overlying Permian units (the Cloud Chief, Doxey, and Elk City Formations), but also in the large number of chaotic blocks of Cretaceous strata that are scattered from northern Washita County northward across much of northwestern Oklahoma (Stanley, 2002; Johnson and others, 2003; Fay, 2010; Suneson, 2012).

Early field studies in western Oklahoma have described the erratic dips of outcropping strata. Gould (1902) was the first to describe dips of 20 to 40 degrees in various directions, even within small areas. He ascribed these erratic structures to dissolution in underlying gypsum beds (probably those in the Blaine Formation). Subsequent workers made similar field observations, and also attributed the chaotic structures to gypsum dissolution and collapse. It is now clear that gypsum dissolution is not the cause of these chaotic structures, except around the fringes of the Anadarko Basin where gypsum beds are within 10-20 m of the land surface.

Gypsum beds (or anhydrite at depth) do underlie most parts of the Anadarko Basin, but they are too thin and too deep in most areas for their dissolution to cause disrupted bedding or collapse of Cretaceous strata. Gypsum/ anhydrite beds in the Blaine Formation are 1-6 m thick, but typically they are at depths of 50-500 m. The only other unit with gypsum/anhydrite more than $2 \mathrm{~m}$ thick in the basin is the Cloud Chief Formation: the basal gypsum, which is up to $30 \mathrm{~m}$ thick in eastern Washita and southeastern Custer Counties, thins sharply to the west and is only 1-4 m thick and is 50-150 m deep in most other parts of the basin. Clearly these two gypsumbearing units are too thin and too deep to contribute to the extensive areas of disrupted outcropping strata, although they may cause subsidence and collapse where they are only about 10-20 m deep.

Recognition that the collapse structures were due to salt dissolution and collapse (not gypsum dissolution) was made in 1963 when Johnson (1963) noted: "Where the Yelton salt is known to be present in subsurface, outcropping strata in the overlying Cloud Chief, Doxey, and Elk City are undisturbed and dip at angles of but 1 or 2 degrees. At several places where the salt is known to be absent... the surface beds are highly disturbed and dip in all directions at angles up to 25 degrees.”

I later served on the thesis committees of several University of Oklahoma students who were doing field mapping in Beckham and Washita Counties, and asked them to make maps showing locations within their study areas where surface rocks were undisturbed or disturbed. The work by these students (Smith, 1964; Richardson, 1970; Zabawa, 1976; Moussavi-Harami, 1977) bore out the spatial relationship between the absence of Yelton salt and the presence of collapse structures in outcropping rocks. Suneson (2012) also recognized the relationship between Yelton salt karst and the distribution of collapsed blocks of Cretaceous strata in southwest Custer County, Oklahoma, just north of the Canute-Burns Flat area (discussed below).

The original extent of the Yelton salt in the Anadarko Basin is unknown. On both the north and south flanks of the synclinal basin, all the salt appears to have been dissolved (Figure 2). Along the axis of the basin, where the salt is thicker and more deeply buried, either all of the salt is still present or only some of the upper salt beds have been dissolved.

Most of the collapse structures are characterized by small- to moderate-sized areas (up to one or several hectares in size) where Permian strata dip at angles of 5-25 degrees, and strata in adjacent areas may dip in another direction, or may even appear to be undisturbed. The various blocks have subsided irregularly into the underlying cavities as salt was being dissolved. In addition, it is likely that some of the collapse structures are breccia pipes, which are cylindrical or irregular columns of broken rock (rubble) that are down-dropped into deep-seated salt cavities. It is likely that some of the Cretaceous collapse blocks are, in fact, the present-day outcrops of breccia pipes wherein Cretaceous strata were dropped some $50 \mathrm{~m}$, or so, and are now juxtaposed with Permian strata.

\section{Study Areas}

Four areas of salt dissolution and collapse show the geographic range of salt karst and resultant collapse in the Anadarko Basin (Figure 1). Oklahoma examples are: 
1) Beckham-Washita County line; 2) Canute-Burns Flat area, Washita County; and 3) northwest Beaver County. A fourth example is the Palo Duro Lake area, Hansford County, Texas.

\section{Beckham-Washita County Line, Oklahoma}

The Yelton salt is dissolved on the north and south sides of the Anadarko Basin in Beckham and Washita Counties, Oklahoma (Figure 2). The Yelton is the youngest salt unit in the basin, and it has been encountered at depths ranging from about 200 to nearly $400 \mathrm{~m}$ along the axis of the basin (Jordan and Vosburg, 1963). At shallower depths, on the flanks of the basin, the salt has been partly or totally dissolved, and overlying strata have collapsed into the salt-karst cavities.

The Yelton salt is about $66 \mathrm{~m}$ thick in the Shell LPG \#1 Yelton well (the type well for the Yelton salt). It is as much as $87 \mathrm{~m}$ thick at the salt depocenter, about $8 \mathrm{~km}$ to the west of the Yelton well (Jordan and Vosburg, 1963), and it thins gradually to the north and south until it thins abruptly at its dissolution front (Figure 2). Cores and electric logs of the Yelton salt in the type well indicate that the unit is about $75-80 \%$ halite, and the remainder is red-brown and green-gray shale occurring as interbeds or as irregular masses within impure salt.

Collapse structures and disturbed bedding in outcropping strata of Beckham and Washita Counties have been well documented by field investigations (Smith, 1964; Richardson, 1970; Zabawa, 1976; Moussavi-Harami, 1977; Suneson, 2012). These chaotic-bedding features are outside of the area now underlain by Yelton salt, and correctly have been interpreted to result from salt dissolution and subsequent collapse.

Breccia pipes may well be present in this area (Figure 2 ), as there are many small chaotic collapse blocks of Cretaceous rocks exposed in the Canute area at the north end of the cross section (Richardson, 1970; Johnson and others, 2003). These Cretaceous blocks in the Canute area, and farther north, are commonly less than one hectare in size, but locally are up to 5-10 hectares.

\section{Canute-Burns Flat Area, Washita County, Oklahoma}

The Canute-Burns flat area, in northwest Washita County, is an excellent site to study dissolution of the Yelton salt and resultant collapse of overlying strata. Mapping of the surface geology by Richardson (1970), and later by Johnson and others (2003), shows the distribution of the collapsed blocks of Cretaceous strata, and this can be directly related to the present-day limits of the Yelton salt on the north side of the Anadarko Basin (Figure 3).

As shown above (Figure 2), the Yelton salt is dissolved on the north flank of the Anadarko Basin, and this causes subsidence and collapse of overlying strata. The Yelton is about $50-70 \mathrm{~m}$ thick in the southwest quarter of the Canute-Burns Flat study area, and it thins, by dissolution, both to the north and to the east (Figure 3). The salt unit is completely missing in the northern and far eastern parts of the area. Suneson (2012) describes an excellent exposure of collapsed Cretaceous rock in Custer County, just several kilometers north of the Canute-Burns Flat area.

By examining outcrops in the area, and comparing them with Yelton-salt distribution and thickness, it is possible

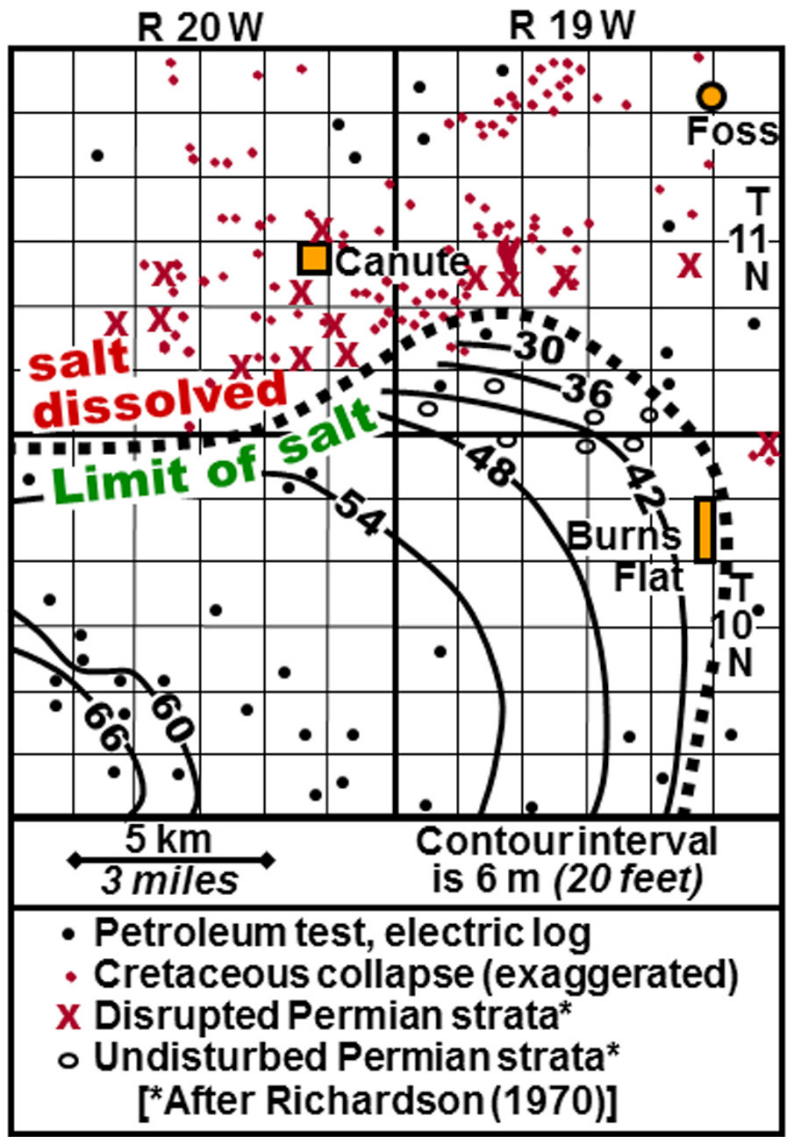

Figure 3. Thickness of Yelton salt showing saltdissolution area and collapse of overlying strata in the Canute-Burns Flat area of northwest Washita County, Oklahoma. Cretaceous collapse structures are mostly less than 7 hectare (2.5 acres). 
to determine where the salt is present and where it is at least partly dissolved. This is accomplished by field mapping of areas where outcropping strata are disrupted or disturbed (that is, where they dip an angles of several degrees, or more), and where they appear to not be disrupted and disturbed, and assuming that the disruption is due to salt dissolution and collapse of all overlying strata. Unfortunately, much of the south half of this study area is mantled by several meters, or more, of Quaternary silt and sands (Richardson geologic map, 1970), and this conceals evidence of whether the bedrock is disrupted or not. Therefore, the precise limits of salt dissolution here cannot be determined by field work alone.

Gypsum beds (or anhydrite at depth) do underlie the Canute-Burns Flat area, but they are too thin and too deep for their dissolution to cause disruption of overlying Permian strata or collapse of Cretaceous rocks. Gypsum/ anhydrite beds in the Blaine Formation are 1-6 m thick, but they are at depths of 350-450 m. The only other unit with gypsum/anhydrite more than $1 \mathrm{~m}$ thick is in the Cloud Chief Formation: the basal gypsum is only about 3

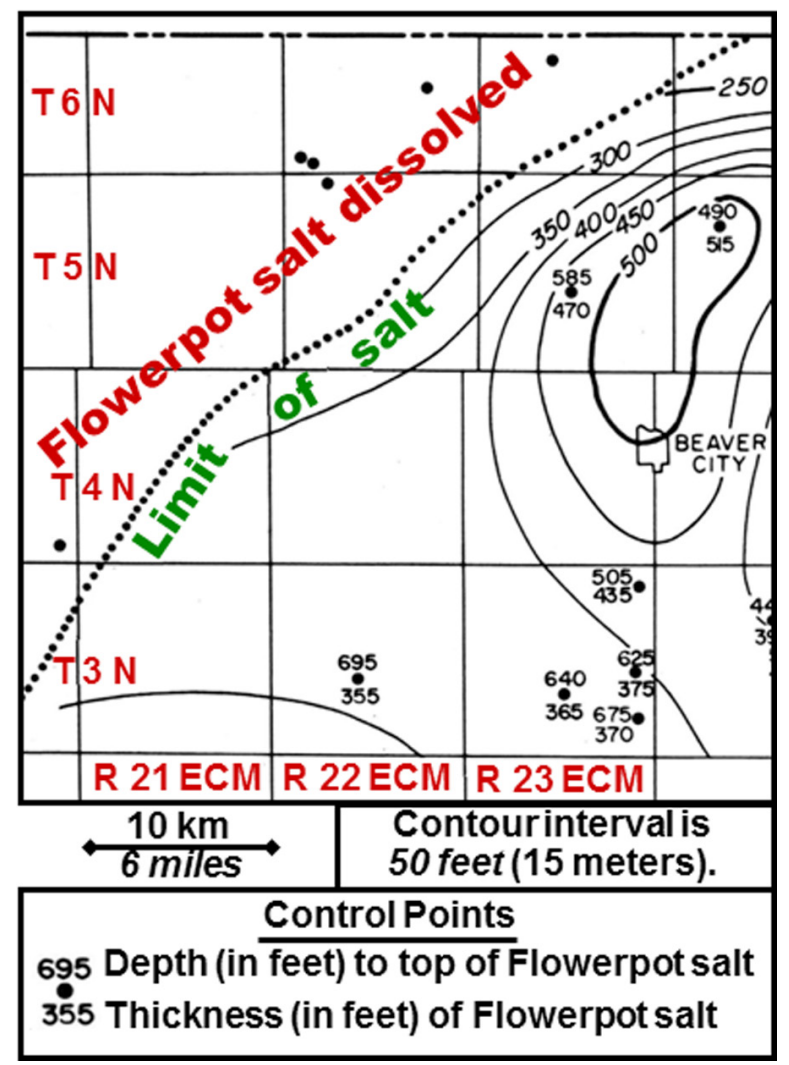

Figure 4. Thickness of Flowerpot salt in northwest Beaver County, Oklahoma (from Jordan and Vosburg, 1963). $\mathrm{m}$ thick and at depths of 100-150 m in the Canute-Burns Flat area-clearly too thin and too deep to contribute to this collapse.

\section{Northwest Beaver County, Oklahoma}

The northwest corner of Beaver County, Oklahoma, contains a dramatic example of salt dissolution and collapse. In most of Beaver County the Flowerpot salt typically is $100-150 \mathrm{~m}$ thick (Figure 4) (Jordan and Vosburg, 1963). However, in the northwest corner of the county the salt unit has been dissolved along a SW-NE trend, and overlying strata have collapsed and subsided about $100 \mathrm{~m}$ (Figure 5) (Jordan and Vosburg, 1963).

The structure at the base of the Blaine Formation (Figure 5 ) is definitely the result of dissolution of the underlying Flowerpot salt. Gypsum beds of the overlying Blaine Formation in the area are 1-4 m thick and are equally thick on both sides of the dissolution zone, so there is no evidence that dissolution of these gypsums plays a part in the subsidence and collapse.

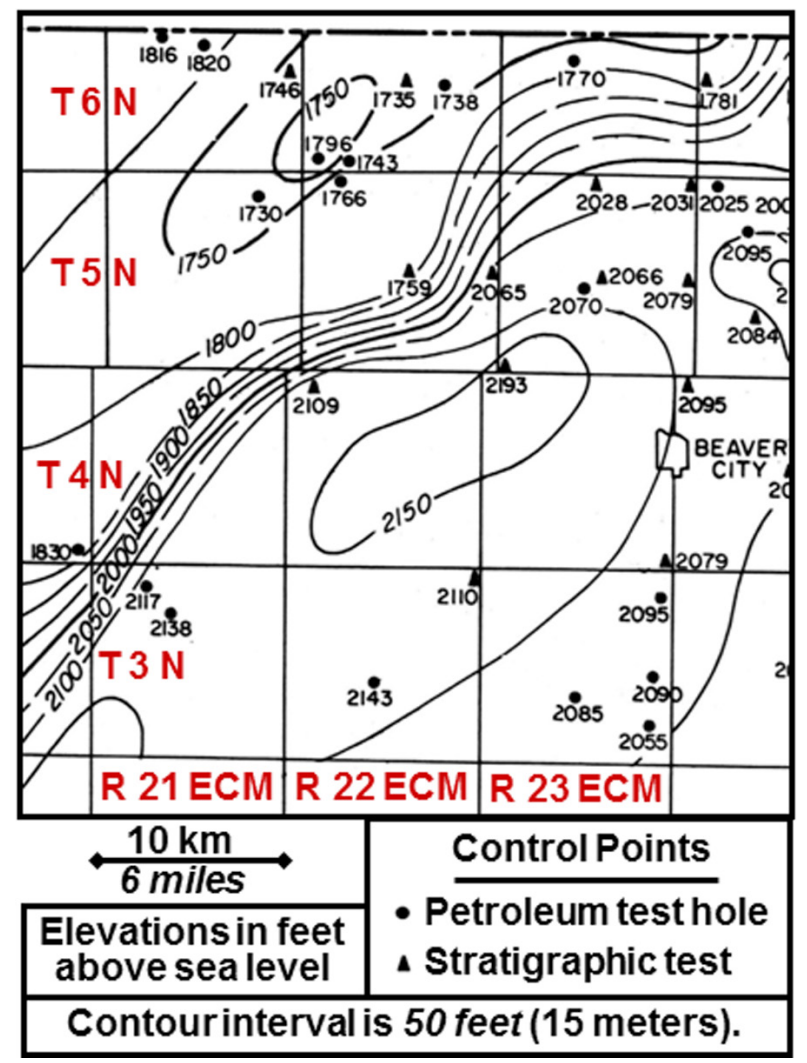

Figure 5. Structure map on base of Blaine Formation in northwest Beaver County, Oklahoma (from Jordan and Vosburg, 1963). 
Strata beneath the Flowerpot salt show no evidence of disturbance in this collapse zone. Structure mapping on the base of the much deeper Wellington evaporites (at a depth of about $1,000 \mathrm{~m}$ ) shows that these strata dip gently, and uninterrupted, to the southeast at a rate of about 3-6 m/km across all of Beaver County (Jordan and Vosburg, 1963). Thus it is clear that the abrupt drop in elevation of the Blaine Formation in northwest Beaver County is due to the dissolution front, and not to any deep-seated structure.

This dissolution-collapse feature is a southern continuation of the Crooked Creek fault that has been well documented and described in Meade County, Kansas (Frye, 1942, 1950). Frye attributed the Crooked Creek fault in Kansas to dissolution of Permian salt and gypsum in the shallow subsurface, and it is now clear that it is principally dissolution of the Flowerpot salt in that area; gypsum (Blaine Formation) dissolution makes

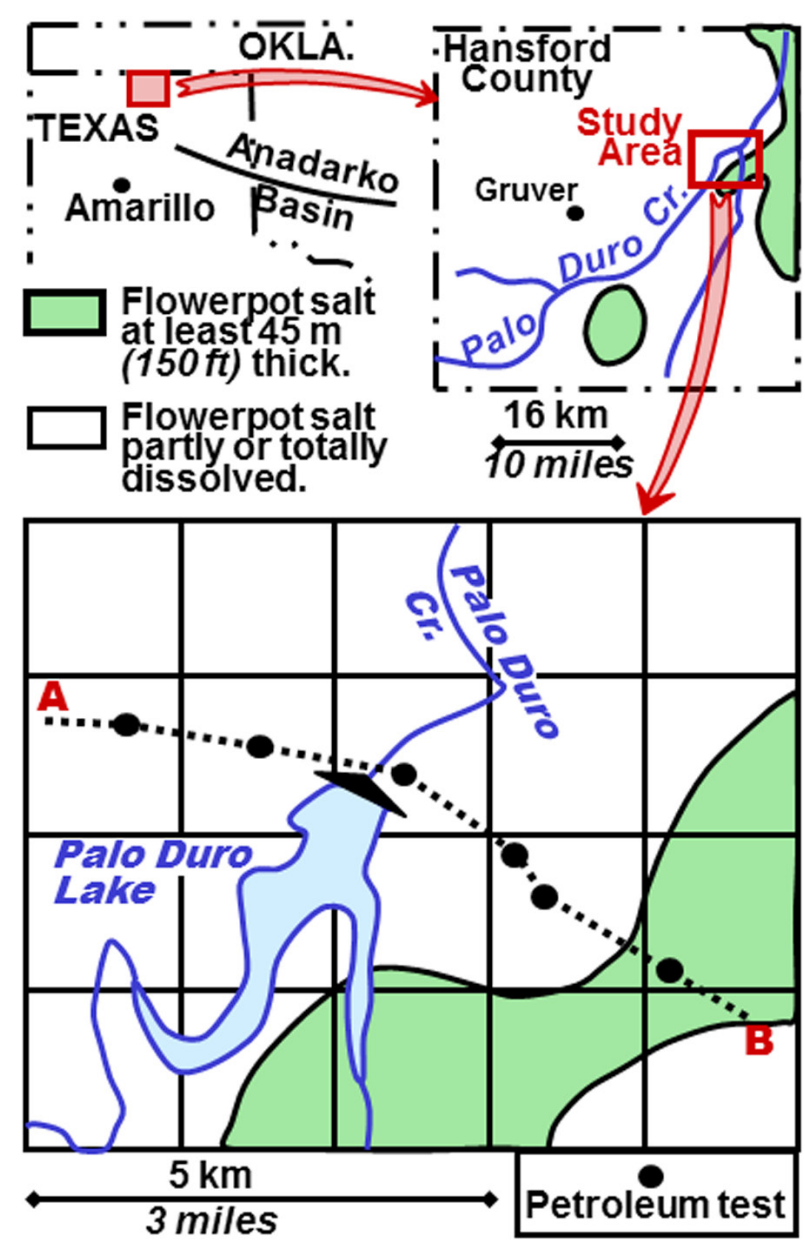

Figure 6. Location maps showing area of salt dissolution and collapse in Hansford County, Texas. Cross section $A-B$ shown in Figure 8. little or no contribution to subsidence in Meade County or in Beaver County.

The timing for dissolution is uncertain. However, owing to the thick accumulation of the Miocene-Pliocene aged Ogallala Formation on the west side of the dissolution front, most of the dissolution apparently occurred prior to or during deposition of the Ogallala Formation (Irwin and Morton, 1969). Marine and Schoff (1962, Plate 1) also show great thicknesses of Ogallala and younger sediments on the west side of the dissolution front. Dissolution and collapse appear to be continuing: Irwin and Morton (1969) report that "recent sudden movement has occurred in Beaver County, Okla., and Hamilton County, Kans., where the land surface subsided several feet over a period of several months.” Merriam and Mann (1957) report a number of recent and past sinks and sinkholes in southwest Kansas.

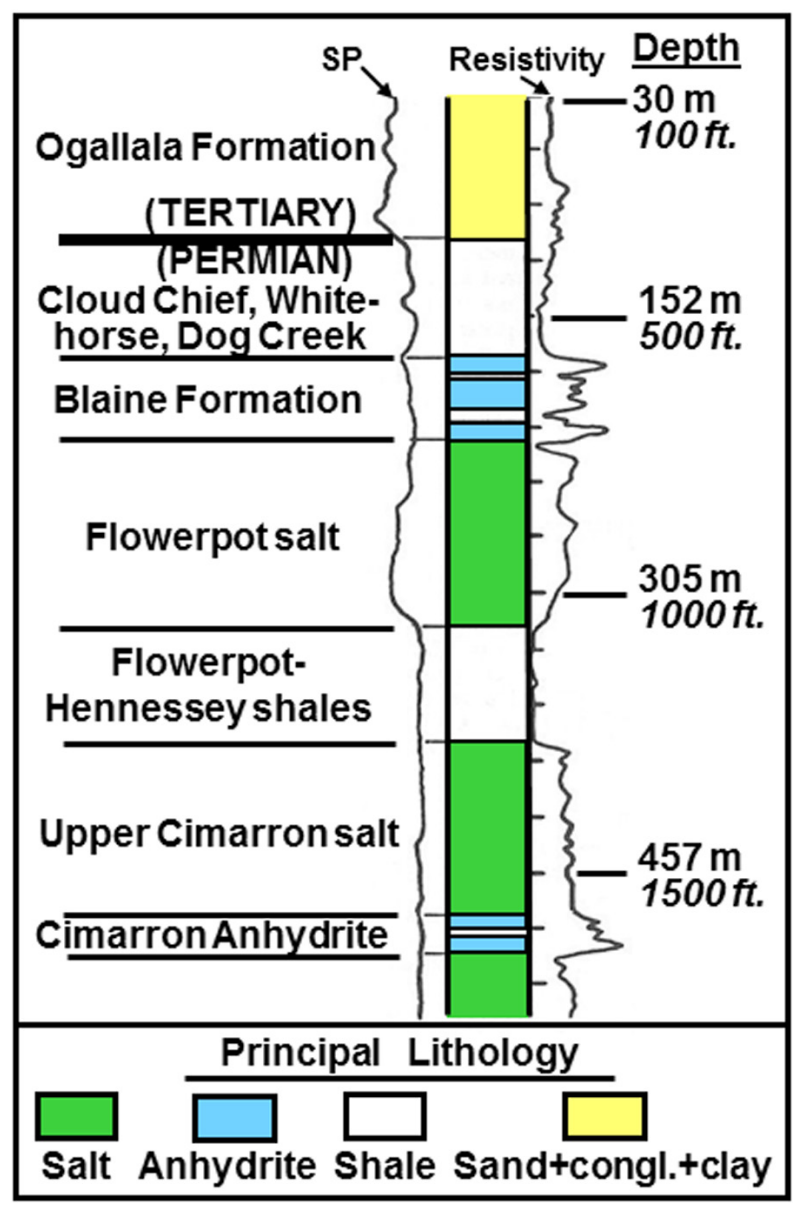

Figure 7. Resistivity and Spontaneous Potential log showing principal lithology in Palo Duro Lake area, Hansford County, Texas (modified from Johnson, 1989). Well is R. R. Fulton \#3 Lasater; H\&TC Survey, Block 45, sec. 72 . 


\section{Palo Duro Lake Area, Hansford County, Texas}

In eastern Hansford County, Texas, Late Cenozoic salt karst has resulted in subsidence and collapse of overlying strata in the vicinity of Palo Duro Lake (Figures 1, 6) (Johnson, 1989b). The Flowerpot salt is 0-107 m thick in the area (Figure 7), and at depths ranging from 180$335 \mathrm{~m}$. However, most of the Flowerpot salt is dissolved beneath most of the study area (Figures 6, 8). Strata beneath the Flowerpot salt are essentially flat-lying and undisturbed (note the Cimarron anhydrite in Figure 8), whereas all the strata above the Flowerpot salt-karst zones are chaotic and are structurally low.

Elevation of the overlying Blaine Formation collapses and undulates, following closely the areas where dissolution occurs in the Flowerpot salt and even in the deeper Upper Cimarron salt.

Principal outcrops in the Palo Duro Lake area are sands and gravels of the Miocene-Pliocene age Ogallala Formation. Based upon well-log studies, the elevation of the Ogallala base is highly irregular, and the caprock, consisting of calcrete and silcrete, is disturbed and collapsed in two large subsidence basins in the area (one of which is shown in Figure 8). Inasmuch as the caprock is disturbed, salt dissolution and subsidence continued, at least locally, until after development of the caprockafter 3.5-2.4 My.

The dissolution front that crosses eastern Hansford County is a southwestward continuation of the northwest Beaver County feature (described above) and the Crooked Creek fault in Meade County, Kansas. There are, however, some patches or areas of Flowerpot salt that are partially or totally unaffected by dissolution farther west in both the Oklahoma and Texas Panhandles (Figure 1). Therefore, the structure of strata above the Flowerpot (the Blaine, Dog Creek,

Whitehorse, and Ogallala strata) can be quite variable: in places they will be horizontal and undisturbed, and elsewhere they will be at least somewhat chaotic and collapsed into underlying salt-karst zones.

\section{Summary}

Widespread Permian salts in the Anadarko Basin are locally dissolved and have resulted in subsidence and/or collapse of overlying strata in parts of western Oklahoma

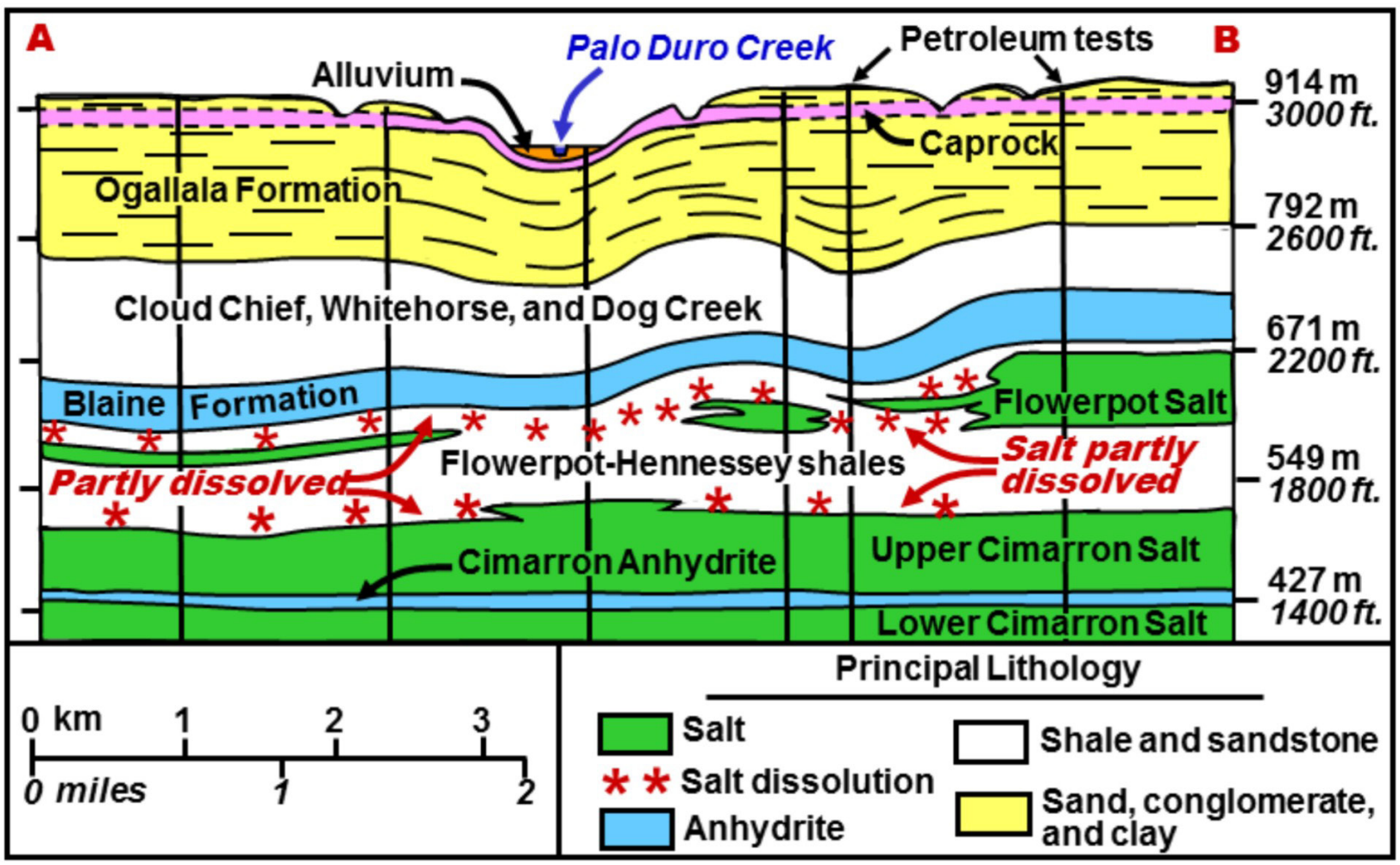

Figure 8. Cross section showing salt dissolution and collapse of overlying strata at Palo Duro Lake in Hansford County, Texas (modified from Johnson, 1989). See Figure 6 for location. 
and the Texas Panhandle. Chaotic structures, collapse features, and breccia pipes are present in outcropping Permian, Cretaceous, and Tertiary strata. These strata normally dip at an angle of less than one degree towards the axis of the Anadarko Basin, but may dip at angles of 5-25 degrees in various directions where an underlying salt unit is partly or totally dissolved.

It is clear that most (if not all) of these collapse features and chaotic dips result from dissolution of salt and collapse of overlying strata into deep-seated zones of salt karst. Whereas gypsum karst and resultant collapse had been proposed in many parts of the Anadarko Basin before, the gypsum beds are only 1-6 m thick and are more than $100 \mathrm{~m}$ deep in these study areas and cannot contribute to the collapse of overlying strata.

\section{References}

Alger RP, Crain ER. 1966. Defining evaporite deposits with electrical well logs. In: Rau JL, editor. Second symposium on salt. The Northern Ohio Geological Society, Inc., vol. 2, p. 116-130.

Fay RO. 2010. Preliminary geologic map of the Foss Reservoir 30’ X 60’ quadrangle, Beckham, Custer, Dewey, Ellis, and Roger Mills Counties, Oklahoma. Oklahoma Geological Survey, Oklahoma Geological Quadrangle Map OGQ-78A. Scale 1:100,000.

Frye JC. 1942. Geology and ground-water resources of Meade County, Kansas. Kansas Geological Survey Bulletin 45. 152 p.

Frye JC. 1950. Origin of Kansas Great Plains depressions. Kansas Geological Survey Bulletin 86 (1). 20 p.

Gould CN. 1902. General geology of Oklahoma. Oklahoma Territory Department of Geology and Natural History 2nd Biennial Report. p. 17-137.

Irwin JH, Morton RB. 1969. Hydrogeologic information on the Glorieta Sandstone and the Ogallala Formation in the Oklahoma Panhandle and adjoining areas as related to underground waste disposal. US Geological Survey Circular 630. 26 p.

Johnson KS. 1963. Salt in the El Reno Group (Permian), Elk City area, Beckham and Washita Counties, Oklahoma. University of Oklahoma, Biennial Geological Symposium, 8th, Proceedings. p. 79-92.

Johnson KS. 1967. Stratigraphy of the Permian Blaine Formation and associated strata in southwestern Oklahoma [PhD dissertation]. Champaign (IL): University of Illinois. 247 p.

Johnson KS. 1976. Evaluation of Permian salt deposits in the Texas Panhandle and western Oklahoma for underground storage of radioactive wastes. Union Carbide Corporation, Oak Ridge National Laboratories, Office of Waste Isolation, Y/OWI/ Sub-4494/1. 73 p.
Johnson KS. 1981. Dissolution of salt on the east flank of the Permian Basin in the southwestern U.S.A. Journal of Hydrology 54: 75-93.

Johnson KS, Amsden TW, Denison RE, Dutton SP, Goldstein AG, Rascoe B Jr, Sutherland PK, Thompson DM. 1988. Geology of the southern Midcontinent, in Sloss, L.L., ed., Sedimentary cover - North American craton, U.S.: Geological Society of America, The Geology of North America, v. D-2, p. 307-359. Also released in 1989 by Oklahoma Geological Survey, Special Publication SP 89-2. 53 p.

Johnson KS. 1989a. Geological evolution of the Anadarko basin, in K. S. Johnson, ed., Anadarko basin symposium, 1988: Oklahoma Geological Survey Circular 90. p. 3-12.

Johnson KS. 1989b. Salt dissolution, interstratal karst, and ground subsidence in the northern part of the Texas Panhandle. In: Beck BF, editor. Engineering and environmental impacts of sinkholes and karst. AA Balkema Publishers, Brookfield, Vermont, Proceedings of the 3rd Multidisciplinary Conference on Sinkholes and the Engineering and Environmental Impacts of Karst, St. Petersburg, Florida. October 2-4, 1989. p. 115-121.

Johnson KS. 1993. Dissolution of Permian Salado salt during Salado time in the Wink area, Winkler County, Texas. In: Love DW, and others, editors. Carlsbad region, New Mexico and west Texas. New Mexico Geological Society Guidebook, 44th Annual Field Conference. p. 211-218.

Johnson KS, Stanley TM, and Miller GW. 2003. Geologic map of the Elk City 30’X 60’ quadrangle, Beckham, Custer, Greer, Harmon, Kiowa, Roger Mills, and Washita Counties, Oklahoma. Oklahoma Geological Survey, Oklahoma Geological Quadrangle Map OGQ-44. Scale 1:100,000.

Jordan L, Vosburg DL. 1963. Permian salt and associated evaporites in the Anadarko Basin of the western Oklahoma-Texas Panhandle region. Oklahoma Geological Survey Bulletin 102. 76 p.

Marine IW, Schoff SL. 1962. Ground-water resources of Beaver County, Oklahoma. Oklahoma Geological Survey Bulletin 97. 74 p.

Merriam DF, Mann CM. 1957. Sinkholes and related geologic features in Kansas. Kansas Academy of Science, Transactions 60 (3): 207-243.

Moussavi-Harami R. 1977. Areal geology of Cordell area, central Washita County, Oklahoma [MS thesis]. Norman (OK); University of Oklahoma 76 p.

Richardson JL. 1970. Areal geology of western Washita County, Oklahoma [MS thesis]. Norman (OK): University of Oklahoma. 67 p. 
Smith AH. 1964. Areal geology of Elk City area, Beckham and Roger Mills Counties, Oklahoma [MS thesis]. Norman (OK): University of Oklahoma. 64 p.

Stanley TM. 2002. Geologic map of the Woodward 30' X 60' quadrangle, Ellis, Dewey, Roger Mills, and Woodward Counties, Oklahoma. Oklahoma Geological Survey, Oklahoma Geological Quadrangle Map OGQ-40. Scale 1:100,000.

Suneson NH. 2012. Custer County oysters. Oklahoma City Geological Society Shale Shaker 62 (6): 422-429.

Zabawa PJ. 1976. Investigation of surficial structural geology of portions of Beckham, Custer, Roger Mills, and Washita Counties, Oklahoma [MS thesis]. Norman (OK): University of Oklahoma. 98 p. 


\section{SINKHOLES AND THE ENGINEERING AND ENVIRONMENTAL IMPACTS OF KARST}

\section{PROCEEDINGS OF THE THIRTEENTH MULTIDISCIPUNARY CONFERENCE}

\section{May 6 through 10, 2013 Carlsbad, New Mexico}

\section{EDITORS:}

Lewis Land

New Mexico Bureau of Geology and Mineral Resources

and National Cave and Karst Research Institute

Daniel H. Doctor

U.S. Geological Survey

J. Brad Stephenson

$C B \& I$

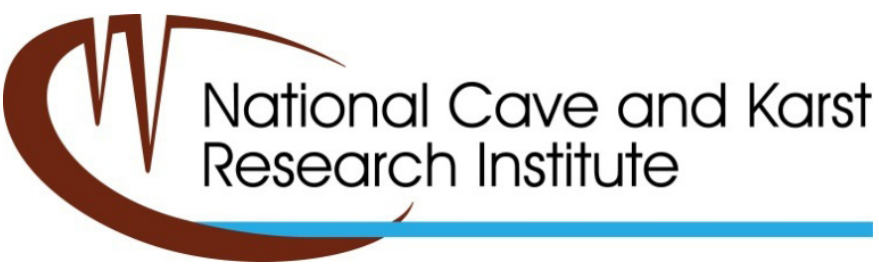

